\title{
Socio-Historical Background of the Bajo Tribe in Tomini Bay
}

\author{
Muhammad Obie ${ }^{1}$ \\ ${ }^{1}$ Department of Sociology, State Islamic University of Sultan Amai Gorontalo, Indonesia \\ Correspondence: Muhammad Obie, Department of Sociology, State Islamic University of Sultan Amai \\ Gorontalo, Indonesia. Tel: 62-81354790642. E-mail: obiclimber@gmail.com
}

Received: July 8, 2018

Accepted: August 10, 2018

Online Published: August 31, 2018

doi:10.5539/ach.v10n2p73

URL: http://dx.doi.org/10.5539/ach.v10n2p73

\begin{abstract}
This research aimed to analyze the socio-historical background of the Bajo Tribe to gain an academic explanation of the existence of the Bajo Tribe in Tomini Bay. Data collection techniques were conducted through indepth interview, passive participation observation, and Focused Group Discussion (FGD). Data collection was also done through literature study by collecting documents related to this research topic. The results showed that the Bajo tribe who currently live and settle in Tomini Bay is believed to be moving from the bay of Bone, South Sulawesi. They ran the ocean to form settlements in Tomini Bay. The Bajo tribal settlement in Tomini Bay was originally called Toro Siajeku which in 1901 was inaugurated by the Dutch Colonial Government into a village. The inauguration of the settlement which has now changed its name to Torosiaje Village is the momentum of the solidifying of sedentary life for the Bajo Tribe community in Tomini Bay.
\end{abstract}

Keywords: Socio-history, Bajo tribe, Sea nomads, Tomini bay

\section{Introduction}

The Bajo tribe has different characteristics with other tribal communities in the archipelago in general, because the so-called Bajo tribe cannot be separated by sea and boat. The Bajo tribe is known to prefer living on a boat and moving places according to the potential of fishes to be caught, so dubbed a sea nomad (Zacot, 2008; Saad, 2009). Because of many historical versions of the origin of the Bajo tribe, no one has been able to identify with certainty its origin yet. Geoghegan (1975) mentions that the Bajo tribe is originate from the Southern Philippines. Nuryadin (2010) states that the Bajo community comes from a single family with their union language is baong same. They include Proto Melayu Nation from Funan (Old Malay) which spread throughout Southeast Asia, especially the Philippines, Malaysia, and Indonesia. In Nusantara Archipelago, Indonesia, they spread to Sumatra, Riau, Sulawesi, Maluku, Flores, and others.

Another version states that the Bajo tribe originated from Johor (Sopher, 1965; in Mokhtar \& Saat, 2008). The Bajo tribe entered Indonesia initially stranded on the coast of Bajoe, bay of Bone, South Sulawesi. King Bone allowed them to establish a village on the coast of Bajoe, on condition that they become the navy of the Kingdom of Bone and must defend the kingdom from enemy attacks. It can not be ascertained since when the Bajo tribe has been in bay of Bone, but by 1700 they were known to be in the bay of Bone. The history of Gowa states that there had been wars between the Kingdom of Bone and the Dutch in 1825 and 1909, the Bajo tribe also fought to defend Bone from the shoreline (Mokhtar \& Saat, 2008). Accept the hypothesis that the Bajo tribe originated from Johor (Sopher, 1965; in Mokhtar \& Saat, 2008), Eastern Indonesia is believed to be the earliest area they occupy. Because of the lack of evidence, it is difficult to ascertain since when the Bajo tribe began to occupy the eastern islands of Indonesia. One source that can be used as evidence is "Lontara Bajo", a note inscribed on leaf lontara that describes some things about the life or culture of the Bajo Tribe in Indonesia. It is believed to be the same age as the Lontara Bugis recorded in the fifteenth century and as evidence that the Bajo tribe had been in the Sulawesi Islands long before the 15th century (Mokhtar \& Saat, 2008).

A number of anthropologists noted that the love of the Bajo tribe against the sea began as they tried to avoid war and turmoil on land. The community finally felt the peace at sea, since it was the rise of boatmen fully alive on water (Saad, 2009: 32). The Bajo community initially lived on a boat called a bido. The community lives on and off, moving in groups to different places according to the choice of fishing location. Therefore, the Bajo people are often called sea nomads or sea gypsies (Sopher, 1971; Brown, 1993, in Suyuti, 2011: 2). Sea for the Bajo people is absolute, because in addition as a residence, as well as a place to earn a living. This is because the life of the people 
of Bajo is fully devoted to the cultivation of marine resources. The sea for them is used as the source of life (Mamar, 2005, Suyuti, 2011).

Soesangobeng's research (1977) in Bajoe, South Sulawesi, explains that the Bajo Tribe's dwelling was originally above a bidok (boat) until the 1930s. In early 1935 they began to build kampoh (permanent residence). From this kampoh then they built babaroh at tidal beach. Babaroh is a temporary residence of the Bajo Tribe to rest and process seafood. All construction materials come from the surrounding environment, such as mangrove wood as a support pole, roof covering, and bamboo as a floor or wall.

This research attempts to answer questions about the socio-historical background of the Bajo tribe who currently live on the coast of Tomini Bay. The Bajo tribe in Tomini Bay still remains a question mark because of its very different cultural characteristics with other local people. In addition, the study also explicitly outlines geographical positioning, accessibility, demographics, to the customs and social interactions of the Bajo Tribe in Tomini Bay.

\section{Research Methods}

The types of data collected in this research were primary data and secondary data. The primary data were obtained from a number of informants through in-depth interview techniques. The informants were selected through snow ball technique. Besides through in-depth interviews, primary data collection was also done through observation of passive participation and Focused Group Discussion (FGD). Meanwhile, secondary data were obtained through document studies.

Observation of passive participation is to observe the subject of the study openly, but the researcher is not involved in the object of research activity (Stainback, in Sugiyono, 2009:66). Meanwhile, an in-depth interview is a conversation with a specific purpose (Moleong, 2007:186). The intent of conducting interviews are to constructing people, events, organises, feelings, motivations, demands, concerns and others (Lincoln and Guba, 1985). As for data collection through Focused Group Discussion (FGD), that is to explore the topic of the problem in more depth and to get more accurate information because it allows the participants to check each other's information submitted. To obtain credible data, the data is tested through triangulation, ie checking the credibility of data from various sources in various ways and at various times. Thus there is triangulation of sources, triangulation of data collection techniques, and triangulation of time (Sugiyono, 2009; Moleong, 2007).

\section{Results and Discussion}

\subsection{Sea Nomads to Settle in Tomini Bay}

Bajo tribal settlements in Tomini Bay, Torosiaje, which until now survive above sea surface, have a long history. Repi (2013) said that the Bajo tribe who settles in Torosiaje today, used to live moving from one place to another by using soppe (tradional boat). They come from Salam Penguh Cape, Moutong Regency of Central Sulawesi Province. In Salam Penguh Cape itself actually moved from Pagimana which is still the province of Central Sulawesi. Previously they came from the Kingdom of Bajo in the Malacca Peninsula, where one day the kingdom was devastated by a great flood that led to the loss of the princess. The king finally ordered all his people to search for his princess by boat, while the one who survived in the kingdom only the king and some of his bodyguards. In search of the missing princess, they find the Kingdom of Gowa, South Sulawesi, the princess also found there. Short of story, the king and some guards then intend to pick up the princess, but eventually the princess was married to King of Gowa who has been long life celibacy. The Bajo tribe is then living settled in the bay of Bone, until finally there is a dispersed. Before settling in Tomini Bay, Torosiaje, the Bajo Tribe was moving from the bay of Bone to Pagimana, Central Sulawesi. After settling for some time in Pagimana, they moved again to Salam Penguh Cape, Moutong Regency of Central Sulawesi Province.

Suharjo (2006) states that the existence of the Bajo tribe in Salam Penguh Cape finally known by King of Moutong. King of Moutong then summoned one of his guards to summon the Bajo tribe to explain the purpose of his presence in Salam Penguh Cape. After the Bajo tribe leader met the King of Moutong, they then get freedom to seek livelihood in the kingdom of Moutong. After obtaining the blessing of King of Moutong, the Bajo tribe leader and his crew checked the situation along Salam Penguh Cape, and stated in the Bajo language, kita pasemba matoro ore 'we will stop at the cape' (the cape is Torosiaje, where the Bajo tribe settles to this day). The group of the Bajo tribe was then united open the cape by cutting down trees on the outskirts of natural harbors with the intention that housing can be built around the port.

Over time the cape began to open well, so that among them there has been trying to build houses on the edge of the harbor of nature. Some of them settled with their families there and others stayed on their boats. They are satisfied with the sea products in that place so they choose to settle. The effect of their steadfastness, confidence, and hard work, the cape then promontory spread all over the place. At that time the ammount of the Bajo tribe were 11 heads 
of family with the ammount of souls as many as 35 people. The inhabitants of the cape then grew more and more, along with the increasing number of other Bajo tribes who previously inhabited other beaches in Central Sulawesi sailed and migrated to the cape. Since every person who sailed and stopped at the cape is always asking the name of the cape, the Bajo tribe leader then hold a deliberation to determine the name of the cape that they occupy. The cape is then named Koro Siajeku and agrees Patta Sompa as their leader.

In 1901 Koro Siajeku was inaugurated by the Dutch Colonial Government into a village by appointing Patta Sompa as the village chief. During the leadership of Patta Sompa, in Koro Siajeku Village began to build people's houses regularly above sea surface as a place to live. Over time, the whole people in the community then agreed to change the name of Koro Siajeku by Torosiaje. Repi (2013) states that the name of Torosiaje is based on the reason that toro in Bajo language means cape, while siaje is the title for the pilgrim. The pilgrim is Patta Sompa as the first leader and head of the village on the cape, who has been performing the pilgrimage. In line with that, Sompah (2013) states that the name Torosiaje is based on consideration that the first one who finds the cape is the entourage of Haji Patta Sompah. Since it was first inaugurated by the Dutch colonial government in 1901, the Bajo tribal settlement in Torosiaje has experienced several substitutions of the village head as shown in table 1 below.

Table 1. List of village heads who once ruled in Torosiaje viallage

\begin{tabular}{clcc}
\hline Nu. & N a m e & Length of Service & Years of Service \\
\hline 1. & Patta Sompa & 7 years & $1901-1908$ \\
2. & Batter & 5 years & $1908-1913$ \\
3. & Djadda Darise & 31 years & $1913-1944$ \\
4. & Gutja Sompa & 4 years & $1944-1950$ \\
5. & May Pasandre & 2 years & $1950-1952$ \\
6. & Ruhing Sairullah & 3 years & $1952-1955$ \\
7. & May Pasandre & 2 years & $1955-1957$ \\
8. & Nahasing Sairullah & 3 years & $1957-1960$ \\
9. & Ibrahim Tahutu Pakaya & 22 years & $1960-1982$ \\
10. & Mansur Pakaya & 1 year & $1982-1983$ \\
11. & Amin Pakaya & 10 years & $1983-1993$ \\
12. & Seko Menginsi & 1 year & $1993-1994$ \\
13. & Rasyid Sompa & 7 years & $1994-2001$ \\
14. & Hopni Yosep & 4 years & $2001-2005$ \\
15. & Jootje Repi & 6 years & $2005-2011$ \\
16 & Sudiro O. Pakaya & 2 yeaars & 2011 \\
17 & Jekson Sompah & - & 2013 \\
\hline
\end{tabular}

Source: processed from various sources.

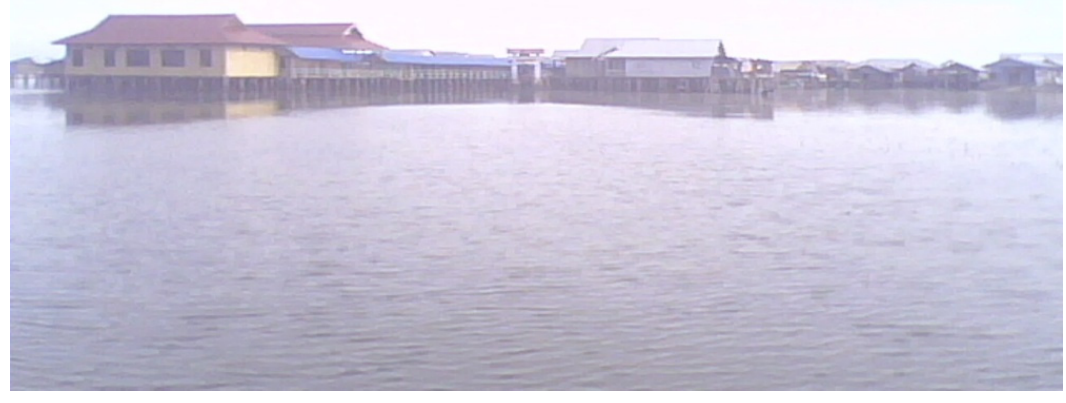

Figure 1. The Bajo tribal settlements in Torosiaje village 
Since Amin Pakaya (1983 - 1993) became the village head in Torosiaje, the Bajo tribe that originally converged to reside on the sea surface began to split, although admitratively still merged in a similar village that is Torosiaje Village. This is caused by the government program that moved the Bajo Tribe to the land through resettlement program. The resettlement was first implemented in the 1984/1985 budget year of 125 families; second phase of 1985/1986 50 households; third phase of 1995/1996 50 families; fourth phase of 1996/1997 50 families; and the fifth phase of 1997/1998 84 heads of family (Obie et al., 2015). The policy has generated major changes to the Bajo tribal community in Torosiaje, with the introduced of the term 'sea Bajo' and 'land Bajo'.

Over time, the Bajo tribe who follows resettlement program and survives on land forms a village. This village is named Torosiaje Jaya which is officially expanded by the government in 2005. Two years later, precisely in 2007, the government reshapes a village named Bumi Bahari Village. This new village is an expansion of the village of Torosiaje Jaya. Thus, the villages of Bajo tribe in Torosiaje consists of three villages, one is on the sea surface and two others on land.

\subsection{Access to the Settlement}

Access to the Bajo tribal villages in Tomini bay is not too difficult. The passage is included in the Trans Sulawesi road. However, extra power needs to be prepared. The choice of transportation to the location is just a landline. The sea transportation of boat is the only option if the visitors want to entry the Torosiaje village on the sea surface. Land transportation and pedestrian boats to the Bajo tribe on the sea surface are always available. From Gorontalo city to the village of land Bajo can be reached by using public transportation of microlet car that can be obtained at the Andalas bus station, Gorontalo city. With a distance of $\pm 260 \mathrm{~km}$, it can be taken for \pm 6 hours. The cost to be incurred is $\mathrm{Rp} 75.000$ per person.besides it can be reached by using a special route that serves the path of the city of Gorontalo-Popayato. It can also be reached by using the connection route. For this second option, visitors first ride a public transport car majors Gorontalo city to the capital of Pohuwato regency, Marisa, with a distance of \pm 160 $\mathrm{km}$. With travel time \pm 4 hours, passengers must provide rent Rp 50.000. After arriving in Marisa city, it continues the journey by public transport to Popayato for $\pm 100 \mathrm{~km}$ with a rental fee of Rp 30,000.

Public transportation from Marisa city to Popayato can be found easily, either special transportation that serves the Marisa-Popayato route, or public transport serving Gorontalo-Moutong route, Central Sulawesi. When visitors choose a transit route Marisa-Popayato car, it will be delivered directly to the village of the Bajo tribe on the beach or to the destination address. However, if forced to ride a transport route leading to Moutong, Central Sulawesi, then visitors will be deployed on the Trans Sulawesi road right in front of the entrance gate of Bajo tribe. Furthermore, to go to the Bajo village for $\pm 1 \mathrm{~km}$ by using motorcycle taxi transport, with the cost of Rp 10,000 per person.

To reach the sea Bajo village, visitors must first walk to the end of the crossing bridge along $\pm 150 \mathrm{~m}$. At the end of the pedestrian bridge, boat taxi is usually available. But if the boat is not available because of taking other passengers, the prospective passengers can wait for a moment in the waiting room available at the end of the pedestrian bridge. To get the sea Bajo village with a distance of \pm 750 meters from the end of the pedestrian bridge,

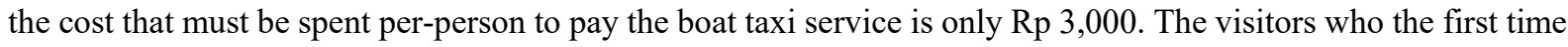
come to this village not to worry, because the boat taxi operators are quite good, friendly, and more priority to the interests of visitors. This has become a common consensus among them, to always serve the visitors well.

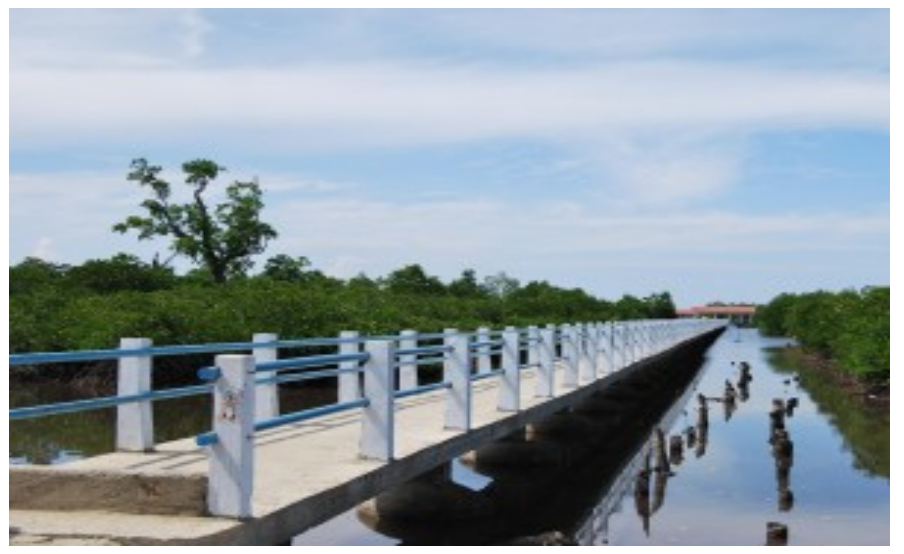

Figure 2. Pedestrian bridge of Torosiaje village 
After a journey of \pm 10 - 15 minutes, the gate "Welcome to Torosiaje" is read clearly, the sign has arrived at the village of sea Bajo and the boat is ready to be propped up. The gate is actually behind the village because the village of Torosiaje formation of the letter ' $U$ ' is facing the open sea. There are about 250 houses on stage, arranged in the formation. All the houses in the habitable homes of about 1,400 are made of wood. In addition to residents' homes, Torosiaje has also established public facilities such as health centers, lodging, mosques, village halls and elementary and kindergarten buildings all built on the sea surface. To connect all the buildings, a corridor of wooden bridges is built around the entire village with a total length of 4,000 meters.

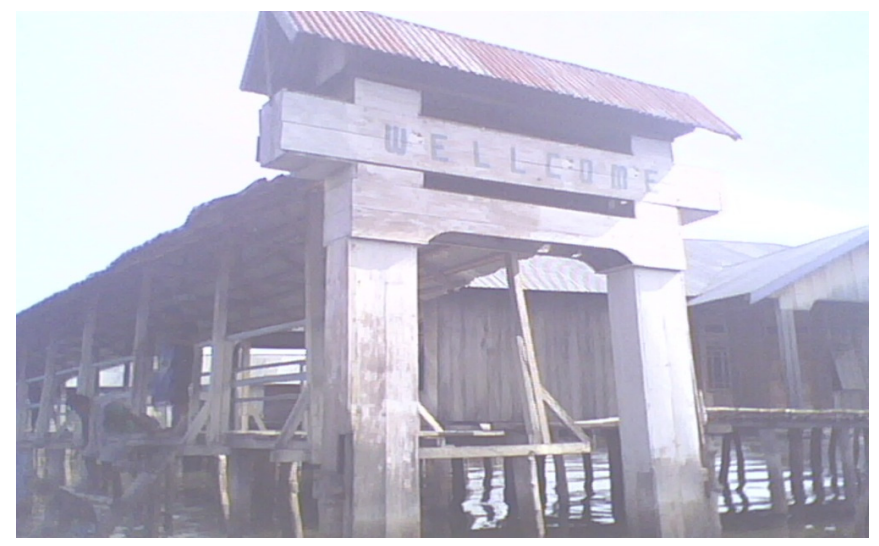

Figure 3. Bajo tribal settlements above sea surface with the greeting "welcome"

\subsection{Demographics}

The amount of the Bajo Tribe residents in 2010 year was 3745 inhabitants, consist of 1002 families. Thus, each household consists of at least 3 to 4 family members. When viewed from the sex ratio, with a composition of 1820 male and 1925 female, shows that the sex ratio of the citizens of the Bajo tribe is 95 . It means that the female population is $5 \%$ larger than the male population. This number is scattered in three villages which become the concentration of the Bajo Tribe villages as shown in table 2 below.

Table 2. Population and sex ratio

\begin{tabular}{clcccc}
\hline Nu. & \multicolumn{1}{c}{ Village } & Men & Women & Total & Sex Ratio \\
\hline 1. & Torosiaje & 578 & 637 & 1215 & 91 \\
2. & Torosiaje Jaya & 650 & 675 & 1325 & 96 \\
3. & Bumi Bahari & 592 & 613 & 1205 & 97 \\
& Jumlah & $\mathbf{1 . 8 2 0}$ & $\mathbf{1 . 9 2 5}$ & $\mathbf{3 . 7 4 5}$ & $\mathbf{9 5}$ \\
\hline
\end{tabular}

Sources: Processed from the monographs of the villages of Torosiaje, Torosiaje Jaya, and Bumi Bahari.

Table 2 data above shows that the highest sex ratio is found in Bumi Bahari village that is 97 , while the lowest is in Torosiaje village with value 91. This figure shows that although in both Bajo villages the percentage of female population is equally greater than men, but the highest percentage of women is in Torosiaje village, which is $9 \%$ larger than the male population. Meanwhile, in Bumi Bahari village the female population is $3 \%$ higher than the male population, and in Torosiaje Jaya village the female population is $4 \%$ larger than men.

The population composition of the Bajo tribe spread in three villages can also be seen based on age structure. Thus, it can be mapped whether the Bajo Tribe belongs to the elderly or younger population.for that, first determined the criteria of population classification based on age composition according to Wirosuharjo (1981).

Table 3. Classification of population based on age composition

\begin{tabular}{ccc}
\hline Age & Elderly population & Young population \\
\hline $0-14$ & $\leq 30 \%$ & $\geq 40 \%$ \\
$15-64$ & $\geq 60 \%$ & $\leq 55 \%$ \\
$65+$ & $\geq 10 \%$ & $\leq 5 \%$ \\
\hline
\end{tabular}

Source: Wirosuharjo (1981). 
Based on the monograph of Torosiaje village, the age composition is as shown in table 4 below.

Table 4. Population of sea Bajo village by age group

\begin{tabular}{|c|c|c|c|}
\hline Nu. & Age group & Total population & Percentage \\
\hline 1. & $0-04$ & 45 & 3,70 \\
\hline 2. & $05-09$ & 65 & 5,35 \\
\hline 3. & $10-14$ & 65 & 5,35 \\
\hline 4. & $15-19$ & 112 & 9,22 \\
\hline 5. & $20-24$ & 143 & 11,77 \\
\hline 6. & $25-29$ & 135 & 11,11 \\
\hline 7. & $30-34$ & 81 & 6,67 \\
\hline 8. & $35-39$ & 78 & 6,42 \\
\hline 9. & $40-44$ & 97 & 7,98 \\
\hline 10. & $45-49$ & 139 & 11,44 \\
\hline 11. & $50-54$ & 133 & 10,95 \\
\hline 12. & $55+$ & 122 & 10,04 \\
\hline \multicolumn{2}{|r|}{ Jumlah } & 1.215 & 100 \\
\hline
\end{tabular}

Source: Processed from the monograph of Torosiaje village.

Table 5. Population of land Bajo by age group

\begin{tabular}{|c|c|c|c|}
\hline Nu. & Age group & Total population & Percentage \\
\hline 1. & $0-04$ & 103 & 4,07 \\
\hline 2. & $05-09$ & 102 & 4,03 \\
\hline 3. & $10-14$ & 151 & 5,97 \\
\hline 4. & $15-19$ & 236 & 9,33 \\
\hline 5. & $20-24$ & 306 & 12,09 \\
\hline 6. & $25-29$ & 304 & 12,02 \\
\hline 7. & $30-34$ & 169 & 6,68 \\
\hline 8. & $35-39$ & 197 & 7,79 \\
\hline 9. & $40-44$ & 194 & 7,68 \\
\hline 10. & $45-49$ & 287 & 11,34 \\
\hline 11. & $50-54$ & 240 & 9,49 \\
\hline 12. & $55+$ & 241 & 9,53 \\
\hline \multicolumn{2}{|r|}{ Jumlah } & 2.530 & 100 \\
\hline
\end{tabular}

Sources: Processed from the monographs of villages of Torosiaje Jaya and Bumi Bahari.

Taking into account of population structure based on the data shown in the table 5 above, it appears that the population with the age range 0-14 years, both in sea Bajo and land Bajo areas amounted to $\leq 30 \%$, ie $19.40 \%$ for sea Bajo village and $14.07 \%$ to land Bajo village. Meanwhile, the age group of 15 years and over is more than $80 \%$. By using the criteria proposed by Wirosuharjo (1981), it can be concluded that the population in the village of Bajo Tribe, both at sea and on land belong to the old population.

Meanwhile, when viewed from the level of education, the majority of the population in the villages of Bajo tribe both in the sea and on land only to elementary school. Many of which until completing elementary school, but not a few who did not finish primary school. This is very closely related to the availability of educational facilities both 
in quantity and its quality. The availability of educational facilities both facilities and infrastructure will be very supportive in improving education. In the Bajo Tribe, the only elementary school building was built in 1952 at sea surface, at that time the entire Bajo tribe lived on the sea surface. As a result, although not all attend school, but the majority of them have graduated from primary school. This is different from junior high school, because the secondary school facilities are not available, very minimal Bajo tribe who until school to junior high school. Before the construction of the First High School building, the Bajo children rarely continue their education. If they want to go to Junior High School then they have to live in a house far from their village.

This condition changed since 2004, when the only junior high school building was built in their village, precisely in the village of Torosiaje Jaya. The same year also built vocational haigh school of marine. The Bajo's understanding of the importance of education is growing, so their children begin to be motivated to continue their education. The result since the 2009 elections to date, there are always representatives of Bajo people who occupy the legislative position. Furthermore, the population according to education level can be seen in table 6 below.

Table 6. Population of sea Bajo village by education level

\begin{tabular}{clcc}
\hline Nu. & \multicolumn{1}{c}{ Education level } & Total & Percentage \\
\hline 1. & Not yet school & 92 & 7,57 \\
2. & Never go to school & 51 & 4,20 \\
3. & Didn't graduate elementary school & 165 & 13,58 \\
4. & Graduated elemntary school & 808 & 66,50 \\
5. & Graduated junior high school & 65 & 5,35 \\
6. & Graduated senior high school & 32 & 2,63 \\
7. & Scholar $\quad$ Total & 2 & 0,16 \\
& & $\mathbf{1 . 2 1 5}$ & $\mathbf{1 0 0}$ \\
\hline
\end{tabular}

Source: Processed from the profile of Torosiaje village.

Table 7. Population of land Bajo village by education level

\begin{tabular}{clcc}
\hline Nu. & \multicolumn{1}{c}{ Education level } & Total & Percentage \\
\hline 1. & Not yet school & 164 & 6,48 \\
2. & Never go to school & 175 & 6,92 \\
3. & Didn't graduate elemnetary schhol & 524 & 20,71 \\
4. & Graduated elementary school & 1331 & 52,61 \\
5. & Graduated junior high school & 124 & 4,90 \\
6. & Graduated senior high school & 164 & 6,48 \\
7. & Scholar $\quad$ Total & 48 & 1,90 \\
& & $\mathbf{2 . 5 3 0}$ & $\mathbf{1 0 0}$ \\
\hline
\end{tabular}

Sources: Processed from the profiles of villages of Torosiaje Jaya and Bumi Bahari.

Based on livelihoods can be seen in tables 8 and 9 below. At sea Bajo village, the majority of the population livelihood as fisherman (95\%), while in land Bajo vilages, the majority of livelihood as farmers (38.19\%). It appears in Table 9 that work as fishermen is no longer the main livelihood for the Bajo tribe, even under entrepreneurs (38.28\%).

Table 8. Population of sea Bajo village by livelihood

\begin{tabular}{ccccc}
\hline Nu. & & Livelihood & Total & Percentage \\
\hline 1. & Fishermen & 321 & 95 \\
2. & Others (bussiness and services) & 17 & 5 \\
& & Total & $\mathbf{3 3 8}$ & $\mathbf{1 0 0}$ \\
\hline
\end{tabular}

Source: Processed the from profile of Torosiaje village. 
Table 9. Population of land Bajo village by livelihood

\begin{tabular}{clccc}
\hline Nu. & & Livelihood & Total & Percentage \\
\hline 1. & Fishermen & 102 & 19,28 \\
2. & Farmers & 202 & 38,19 \\
3. & Livestock & 57 & 10,78 \\
4. & Bussiness & 6 & 1,13 \\
5. & Services & 16 & 3,02 \\
6. & Enterpreneur & 104 & 19,66 \\
3. & Government employees & 42 & 7,94 \\
& & Total & $\mathbf{5 2 9}$ & $\mathbf{1 0 0}$ \\
\hline
\end{tabular}

Sources: Processed from the profiles of villages of Torosiaje Jaya and Bumi Bahari

Meanwhile, when viewed from the religion adopted, it appears that Islam is the only religion adopted by the Bajo tribe, both in the sea village and on land. In the sea Bajo village there is found a mosque, while on the land is found four mosques, each of two mosques in the Torosiaje Jaya village and two mosques in the Bumi Bahari village.

\subsection{Customs and Social Interaction}

The customs of the Bajo tribe is handled by the customary council, led by a customary head and assisted by six members of the customary council. The customary head can not interfere with village affairs, otherwise the village head may interfere in customary matters. There is one area that is equally governed and sanctioned by religion, customs, and government, namely the relationship between men and women, especially between young men and women. In addition to moral sanctions, customary rules protect women. When a young man pushes, strikes, insults a girl or loudly throws it with an object, the girl can complain to a member of the customary council, to the priest or the village head. The young man will be fined. The penalty imposed will be greater if the young man is not a Bajo man (Zacot, 2008).

When the Bajo tribe still lives on the boat, the marriage only takes place amongst its own group. This is because the relationship with the outside community occurs only when the exchange of fish catches. However, today, although the majority marriage still occurs among the Bajo tribe itself, there are some who marry bagai people (not Bajo people). In general the marriage stages of the Bajo tribe can be mentioned below (Suharjo, 2006). The first is the proposal. Before the event was held, the parents of the men came to the women's house to convey their intention that their children loved each other and had plans to proceed to marriage. If the plan is approved by the women, then proceed with deliberation to determine the next step, which is determining the time of proposal. Next is the event of the men's side against the women. At this event, the men must provide equipment to be given to the women such as one piece of white cloth, money dowry, and for those who are able, in addition to these two equipments are also added with the Quran manuscripts and prayer equipment. The second is the implementation of a marriage ceremony, which includes various events, namely marriage ceremony, marriage counsel, and praying.

\section{Conclusion}

Many historical versions of the origin of the Bajo tribe, until now no one can identify with certainty. The Bajo tribe in Tomini Bay, Torosiaje, which hitherto settled above sea surface, has a long history. In the past, this community moved from place to place in ocean by boat. They are believed to be moving from the bay of Bone along Tomini bay to build a settlement called Torosiaje village today. This settlement was inaugurated by the Dutch Colonial Government into a village in 1901. As the resettlement program by the new order government that moved the Bajo Tribe community to the land, causing the residential village of Bajo tribe developed into 3 villages, namely 1 village on the sea surface and 2 villages on land. The main village is located on the sea surface named Torosiaje village, while two others are on land named Torosiaje Jaya and Bumi Bahari Village. These two villages were inaugurated by local governments in 2005 and 2007 respectively.

\section{Acknowledgements}

The greater prayer dan profound thanks to my father, La Siko, and my mothers, Wa Suumi and Wa Nuriima, who took pains to take care of me and seek to pay for my education till able to publish this work. May this work becomes charity for them. May they get forgiveness from Allah s.w.t. and placed in His heaven with the His believers. Aamiin Ya Rabbal Al-Amiin. 


\section{References}

Geoghegan, W. (1975). "Balangingi." In F. M. LeBar (Ed. ), Ethnic Groups of Insular Southeast Asia (Vol. 2, pp. 6-9). Philippines and Formosa. New Haven: HRAF Press.

Lincoln, Y. S., \& Guba, E. G. (1985). Naturalistic Inquiry. Newbury Park, CA: Sage Publication

Mamar, S. (2005). Kebudayaan Masyarakat Maritim. Palu: Tadulako University Press.

Mokhtar, M. K., \& Saat, G. (2008). Urbanisasi Dan Pembangunan Komuniti Peribumi Suku Bajo di Teluk Bone, Sulawesi Selatan. Jurnal Politik, 4(2), 397-419.

Moleong, L. J. (2007). Metodologi Penelitian Kualiatif (Edisi Revisi). Bandung: PT. Remaja Rosdakarya.

Nuryadin, L. O. T. (2010). Kapital Sosial Komunitas Suku Bajo: Studi Kasus Komunitas Suku Bajo di Pulau Baliara, Provinsi Sulawesi Tenggara. Disertasi, FISIP UI, Depok.

Obie, M., Soetarto, E., Sumarti, T., \& Saharuddin. (2015). Sejarah Penguasaan Sumber Daya Pesisir dan Laut di Teluk Tomini. Paramita, 25(1), 73 - 87

Repi, J. (2013). (Personal Communication) Mei.

Saad, S. (2009). Bajo: Berumah di Laut Nusantara. Jakarta: Coremap

Soesangobeng, H. (1977). Perkampungan Bajo di Bajoe. Laporan Penelitian: PLPIIS Ujung Pandang.

Sompah, J. (2013). (Personal Communication) Mei.

Sopher, D. E. (1971). The Sea Nomads: A Study of Maritim Boat People of Southeast Asia. Singapore: The Nation Museum.

Sugiyono. (2009). Memahami Penelitian Kualitatif. Bandung: CV. Alfabeta

Suharjo, S. (2006). Budaya Masyarakat Bajo di Desa Torosiaje Kabupaten Pohuwato. Manado: Balai Kajian Sejarah dan Nilai Tradisional.

Suyuti, N. (2011). Orang Bajo di Tengah Perubahan. Yogyakarta: Ombak.

Wirosuharjo, K. (1981). Dasar-Dasar Demografi. Jakarta: Lembaga Demografi.

Zacot, F. R. (2008). Orang Bajo Suku Pengembara Laut: Pengalaman Seorang Antropolog. Jakarta: Kepustakaan Populer Gramedia (KPG)

\section{Copyrights}

Copyright for this article is retained by the author(s), with first publication rights granted to the journal.

This is an open-access article distributed under the terms and conditions of the Creative Commons Attribution license (http://creativecommons.org/licenses/by/4.0/). 